\author{
Page \\ The Fraternity of Science . . . . . . 91 \\ Industrial Chemical Analysis. By Dr. D. D. Pratt . 94 \\ Preparation of Ores for Metallurgical Treatment. By \\ Prof. J. A. S. Ritson, O.B.E. . . . . . \\ A Generalization of Abelian Integrals. By Dr. Patrick \\ Du Val. . . . . . . . . 97 \\ Steam, Air and Gas Power . . . . . . 98 \\ Fungi in Relation to Man. By Dr. J. Ramsbottom, O.B.E. 100 \\ A Record of the Changing Face of Britain. By Dr. \\ Vaughan Cornish . \\ Direct Petrol Injection versus the Carburettor for the \\ Internal Combustion Engine. \\ Obituaries : \\ Sir Arthur Evans, F.R.S. (With an appreciation by \\ Prof. J. L. Myres, O.B.E., F.B.A.) \\ News and Views \\ Letters to the Editors: \\ Diffuse Spots in X-Ray Crystal Photographs.-Sir \\ William Bragg, O.M., K.B.E., F.R.S.
}

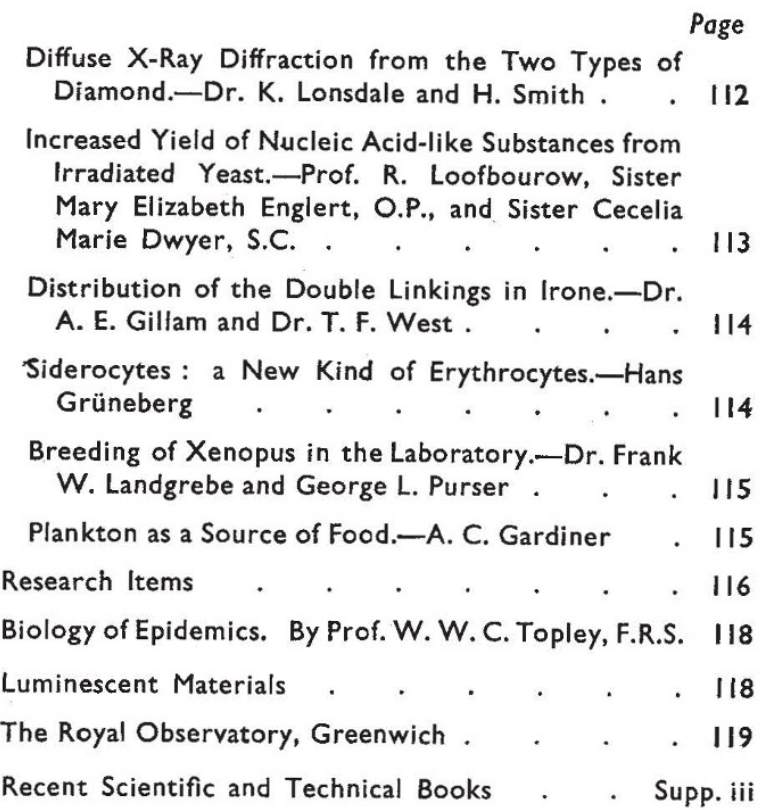

\title{
THE FRATERNITY OF SCIENCE
}

$\mathrm{T}$ HE early years of the twentieth century saw a recrudescence of the movement towards international intercourse in science. The natural philosophers of previous centuries, so far as they were free to carry on their studies, enjoyed a peculiar individual licence to visit and maintain communication with their brethren in other lands. With the growth of science itself, those associated with it began to band themselves together for the more frequent discussion of the many topics in which they were interested, and it was natural that such groups, at first local, should with the improvement of communications become national in scope. The national bodies continued to maintain a limited amount of intercourse by the exchange of publications and by the election of distinguished men of science as foreign members, but this in turn became inadequate to meet the needs of the rising tempo of scientific diseovery and its applications. Thus were born the international associations, with regular meetings held. at intervals of a year or more, attended by individuals and delegate bodies, and with international secretariats to transact their business during the intervals between successive meetings.

Into this healthily growing international intercourse of scientific men was injected the Nazi claim for 'Aryan science' and for 'Nordic superiority' in science as in other fields, followed by the exclusion from the calling of science of all who could not prove their purity of 'Nordic blood'. The result is well known to readers of NAture. Everyone can recall how, in his own particular field, first one, then another distinguished figure, sometimes men of international repute, was forced to leave Germany, often in a state bordering on destitution.

It is worth while examining again the beginnings of this state of affairs. Dr. Julian Huxley traces in brief but telling fashion the rise and decay of science in Germany in a recent pamphlet "Argument of Blood"*. From the fifteenth century onward, the Germanic peoples have made noteworthy contributions to science; as examples of

* Argument of Blood: the Advancement of Science. By Julian Huxley. (Macmillan War Pamphlets, No. 11.) Pp. 48. (London: Macmillan and Co., Ltd., 1941.) 3d. net. 
outstanding men Dr. Huxley mentions Albrecht Dürer, Kepler, von Guericke, Leibniz, Goethe, Fraunhofer, Gauss, of the earlier period, and Liebig, Bunsen, Kirchhoff, Abbe, Koch, Ehrlich, Hertz, and Caro, Graebe and Libermann of more recent times. Nevertheless, science was later in achieving organized form in Germany than in England, France or Italy. With the opening of the nineteenth century, however, the modern German university system began to develop under the ægis, and with the aid of, the State, and the attention given to science led, by the middle of the century, to the German university institutions becoming the accepted homes for schools of scientific research built up by the university professors, to which flocked students from other parts of Europe and from the United States. All this time, however, the State retained its hold on the universities, and was able to ensure that research did not lose touch with industrial development.

Incidentally, Dr. Huxley points out that a very substantial part was taken by Jews in this development of science and its applications. Although they formed only about 1 per cent of the population, it is estimated that they have been responsible for some 25 per cent of significant German contributions to science. German anti-Jewish outbursts, Dr. Huxley suggests, may thus be in part a symptom of an inferiority complex.

Their mode of development will account for the difference in outlook between German university institutions and those of Great Britain. The State has always exercised a degree of control which, with the rise of National Socialism, enabled the Nazi Party quickly to abolish all freedom of study. Dr. Huxley refers in particular to events in the Universities of Heidelberg and Göttingen. By 1936, he says, all serious instruction in philosophy at Heidelberg had ceased, and nearly half the staff in that faculty had been dismissed; appointments were being made on political grounds. At Göttingen similar changes were made ; within a year, nearly a quarter of the University staff had been dismissed.

Such drastic changes in the university system of Germany were bound to have repercussions on the output of scientific research as regards both quality and quantity. The former is difficult to assess, but the correspondence columns of NATURE will serve as a criterion of the latter. Here it was noticeable that the number of original contributions to science coming from German institutions quickly decreased; allowance must, however, be made for the fact that support in NATURE for a policy of intellectual freedom had brought the journal into disfavour. Dr. Huxley points out that the deterioration in quality has been most marked in mathematics, physics and pure biology ; whereas in a subject of direct military value, such as aircraft engineering, a number of valuable contributions to knowledge has been made.

Both staff and students were affected by the changes imposed by the Nazi regime. Although it is difficult to obtain statistics relating to university education in the years immediately preceding the War, it is known from the records of societies assisting displaced intellectuals that nearly 2,000 university teachers were dismissed; many posts were filled with 'safe' Party men, but others were discontinued. As a result, the university teacher lost that security of tenure which hitherto had left him free to pursue his investigations and to teach the truth as he found it without regard to political considerations. The effects on the student body were even more striking. The number of students was reduced to nearly one half of what it was before the Nazis assumed power. Military and semi-military studies were given greater prominence, while the course for medical students was reduced by two years. Another innovation, doubtless made in pursuance of the search for 'leaders' who would be both docile to central Nazi control and also sufficiently immature to be fanatical in their adherence to the new regime, was to appoint student bodies under Party guidance and led by students who in some cases were placed outside the jurisdiction of the university authorities. Normal university life was deliberately undermined.

Apart from these direct attacks on learning, one of the most sinister undertakings of the Nazis has been the deliberate distortion of truth, undertaken with the view of providing a seemingly scientific basis for National Socialist ideology. Dr. Huxley very fittingly deals with the so-called 'racial biology', which is taught from the elementary schools upwards. By a profusion of literature, by lectures and by all the guile of propaganda, the superiority of the 'Aryan', 'Nordic' or 'German' race has been drummed into the minds of a generation who have never been allowed to hear its fallacies discussed. It will be a difficult but essential task to undo this work in the years to come.

With all this coercion and suppression of scientific effort, it is not apparent at first glance why Nazi Germany has been able to make such efficient use of scientific and engineering developments for waging war. The answer Dr. Huxley gives-and it will be generally accepted-is that Nazi success has been based on the large store of technical knowledge and the numerous skilled men trained on scientific principles still remaining in Germany ; time will reduce their number and make their training out of date.

So much for effects within Germany itself of 
the suppression of freedom of learning. Sir Richard Gregory, president for the duration of the War of the British Association, and formerly for many years editor of Nature, takes up the tale at this point in "Science in Chains"*, and voices the feelings of men of science outside Germany, who have observed, at first with concern and later with horror, the cramping restrictions imposed on research and the barbaric discipline which have followed in the wake of Nazism.

An early hint of the attitude of the Nazi Party to scientific intercourse was seen in 1934 at the meeting in Berne of the Astronomische Gesellschaft, a body which, though German in origin, is strongly international in character. One of the secretaries was a Jew, and the German delegates to the meeting were ordered to exclude him, and any other Jewish astronomer, from office. The attempt failed, but it eonveyed a warning as to the character of German delegations which would attend scientific meetings outside Germany. Indeed, in 1935, by order of the Minister of Propaganda, all representation at congresses, inside or outside Germany, was put under the control of a Science Congress Centre, on the specious excuse as regards foreign travel that lack of foreign currency made such centralization necessary. Further, all who went abroad for purposes of study or to give lectures were required to report themselves to the local German representative and to the Foreign Organization of the Nazi Party. The object of these regulations was immediately obvious : they were to ensure that only politically 'safe' spokesmen would be allowed to interpret scientific developments in Germany to the outside world. Under such conditions there can be no adequate exchange of scientific views, and science degenerates into an instrument of national aggrandizement.

This intellectual blight, as Sir Richard Gregory terms it, has descended on every country which has come under Nazi control. With the occupation of Czechoslovakia in 1939, all scientific work had to cease ; institutes were closed, and equipment was destroyed or transferred to Germany. Similar measures were taken in Poland, and some of the ancient universities of Holland have suffered. There should be no need to enlarge upon such instances of Nazi repression as it affects science, for many have been recorded in NATURE during the past two years.

What has been the reaction of the world of science to this reversal of the whole trend of scientific intercourse? An early movement was the formation of a body, now known as the Society for the Protection of Science and Learning, to help intellectual workers who have been deprived of their

* Science in Chains. By Sir Richard Gregory. (Macmillan War Pamphlets, No. 12.) Pp. 32. (London: Macmillan and Co., Ltd., 1941.) 3d. net. means of livelihood for racial or political reasons This body has done magnificent work in providing for many such refugees the opportunity of continuing their vocation, and thus has preserved for civilization the intellectual powers of a considerable body of men. Another effect, perhaps slow to gather strength, was the appearance of protests in the scientific Press; these protests were at first cautious, for scientific men did not care to risk the charge of interfering with what might at first appear to be the internal affairs of another country. One result of such protests was, as readers of NATURE will recall, that this journal was "excluded from general use in scientific libraries" in Germany ; it will be noted that the journal was not entirely banned, for apparently it was still of service, and incidentally, as Sir Richard Gregory points out, German publishers continued, until the outbreak of war, to send scientific works to NATURE and other responsible British journals, confident that they would be justly appraised and the reviews accepted by scientific colleagues all over the world.

Another stage in the growing volume of protest was marked by a resolution passed in 1938 by the American Association for the Advancement of Science, in which the democratic principles of science and the need for intellectual freedom in research were strongly urged. "We regard the suppression of thought and of its free expression as a major crime against civilization itself." Since then, the American Association has asked the British Association to collaborate in framing a charter of democracy on scientific principles, and as a first step towards such collaboration, the Division for the Social and International Relations of Science of the British Association has formulated a statement of the democratic fellowship of science.

Freedom of thought and freedom of communication between the scientific workers of all countries are essential to the progress of humanity. Any political system which challenges these cardinal principles threatens the very life-blood of science ; whatever temporary successes it may achieve by tapping existing reservoirs of knowledge and skill, it contains within itself the seeds of decay. Sir Richard Gregory rightly says : "Science would be false to its tradition if it failed to protest against such criminal assaults on the human mind. Its spirit cannot be confined within any national or racial boundaries, and its service cannot be monopolised by any single country, without debasing the principles for which it has always stood. To make race, political convictions, or religious faith, barriers to the pursuit of natural knowledge, means that science in Nazi Germany loses its soul for the purpose of gaining the world." 